\title{
ROMANIAN COMPANIES' WEB-BASED DISCLOSURE CHOICES AND CAPITAL MARKETS
}

\author{
Associate Professor PhD Victoria Bogdan, University of Oradea, \\ e-mail:vicbogdan@yahoo.com \\ Lecturer PhD Cosmina Mădălina Pop, University of Oradea, \\ e-mail:cosminapop@yahoo.com
}

\begin{abstract}
This article aims to investigate the web-based disclosure choices and practices among Romanian companies listed on Bucharest Stock Exchange. Web-based disclosure offers advantages that are absent in paper-based voluntary disclosure: it can be accessed globally at much lower costs and it can be updated much more timely also at much lower costs. Another goal of the paper is to establish the criteria in order to select properly the sample companies. After presenting the advantages and eventual risks of Internet Financial Reporting and analyzing previous investigative reports and articles, this paper investigates the degree to which Romanian listed companies to disclose financial and non-financial information are using the Internet. The web sites of these companies were examined throughout May 2007 to May 2008, with a view to determining which companies present voluntary financial or non-financial data in addition to the Annual Report and Accounts.
\end{abstract}

Keywords: internet financial reporting, mandatory and voluntary disclosure, capital markets, listed companies

JEL Codes: G10, G14, M14, M41

\section{Introduction}

In the modern business environment the objective of financial reporting is to assemble financial information useful for investors, information simplifying decisions related to investment and granting loans. In the last fifteen years, the Internet and applications of it have been increasingly widely employed in modern business operations. In developed countries, the Internet is used with increasing frequency for financial reporting. In our days, numerous Internet applications are successfully employed in business, such as e-commerce, Internet banking and advertising.

According to the modern framework, the objective of financial reporting is to supply useful information to stakeholders. Financial reporting as understood in this paper implies the creation and presentation of accounting information useful to stakeholders. It is well known that accounting information is contained in financial reports that have to be prepared according to a national or international conceptual framework. For the current age is characterized by the globalization of economies and the increasingly liberal flows of people, goods, and capital, financial reporting takes on a new dimension, and is gradually become the language of global business. In this context it is realistic to expect a growth in all Internet based business applications as well. Corporations may, if they want, publish their financial reports on the Internet and thus make them easily accessible to a large number of users, all around the world. If the financial reports are Internet published, users can find them fairly simply and rapidly if they know the URL. But even if they do not know the exact address, they can search for the financial reports that interest them with the help of various Internet search engines. 
Webster (2002) has mentioned the concept of "Globalization of Communications" and had described it like a phenomenon as supportive as well as contradictory. He has expanded on this point by mentioning that the information provided by companies via mediums such as the Internet may have a negative consequence for the company. An example can be a news release that would negatively affect the share price of the firm. At the same time, mediums like the Internet are offering exposure of the company to many more audiences than was possible without the presence of the Internet. Webster (2002) further explains that globalization requires and at the same time enhances an "information infra-structure". According to this author the following are the elements of this infra-structure:

- World-wide expansions of services that collect information, analyze and distribute it, and add value by analyzing and collating it.

- Globalization requires the construction and where necessary, enhancement of computer and communications technologies.

- This information structure has resulted in the growth of information flows at a quite extraordinary rate.

The point Weber (2002) has made is that technologies such as the Internet are supporting and are being supported by the globalization process. This exposes the company to a wider range of users, thereby increasing responsibility to provide quality information to not just one, but multiple sets of users.

Website as informational device has two advantages that are absent in conventional (printed based) ones. Firstly, information contained in corporate website can be accessed throughout the world at significantly low cost. Secondly, it is more possible for companies to continously update their information also at low cost. Companies are nowadays using their websites to communicate their information to their existing and potential stakeholders. By doing so it is expected that stakeholders are able to receive required information much more timely. Information displayed to the stakeholders can be in quantitative, whether financial or non-financial or qualitative.

\section{The concept of mandatory and voluntary disclosures in accounting}

Investors use information in the valuation process of a company. According to Breton and Taffler (1995), the accounting information disclosed by the company is one of the most important information sources for investors and analysts when valuing a company. The supply of information disclosure from companies can be provided in a number of ways and are of different types. There is regulated and non-regulated information dissemination from the companies. Regulated disclosures called also mandatory, are financial reports such as the annual report and the financial statements, whereas non-regulated information is optional and disclosed on a voluntary basis. Voluntary information can be disclosed via diverse communication vehicles, including company specific reports, press releases, presentations and conference calls (Strom, 2006). Voluntary information disclosure is information provided in addition to mandatory requirements. Mandatory requirements are prescribed by regulations issued by governmental bodies. The mandatory disclosure is commonly saw like the minimum level of information the company must provide in its annual report or prospectus and financial statements.

Disclosure of mandatory information is a very important service that a business can offer its users as it saves on time and costs. The value of the information disclosed on the web depends on the degree of reliability and security offered. In opinion of Avallone and Veneziani (2002) mandatory data content the following pieces: complete financial statements, auditors' report, complete annual or six monthly report, additional statements and highlights.

Voluntary information can also be provided in the annual report or prospectus. Authors like Vergoossen, 1993; Neu et. al, 1998; Arnold and Moizer, 1984, have noted that the most important sources of information for investors and analysts are the annual report and financial statements. 
Avallone and Veneziani (2002) in their study concerning the models of financial disclosure on the Internet - a survey of italian companies, considered that voluntary disclosure information includes all those details not included in legal mandatory requirements. They examined four groups of voluntary data: financial disclosure, data of an institutional nature, information connected to the business model and other information. In their research methodology we can found voluntary disclosure information regarding: segmental reporting, financial ratios, social report, environmental report, draft financial analysis, ownership structure, management data, corporate history, corporate strategies/business areas, market development, $\mathrm{R} \& \mathrm{D}$, customers/suppliers/sales and distribution channels, operating data (number of customers, volumes of trade, turnover etc.), press coverage, press release, value drivers, market share, investments, business model description, commercial structure, SWOT analysis, competitor analysis, quality control, analysts meetings, corporate/financial calendar, letter to shareholders, market consensus and stock exchange quotations.

Much of the analytic work on voluntary disclosures in accounting builds on the work of Verrechia (1983) or Dye (1985). In Essays on Disclosure, Verrecchia (2001) considered that economics-based models of disclosure establish a link between financial reporting and the economic consequences of that activity. Without such a link in his opinion, research in financial accounting is open to the charge that it studies bookkeeping rules and opinion promulgations, but in the absence of any economic motivation. Verrecchia (2001) discussed in his work disclosure in the context of capital markets, topic that seem to have gained some prominence in the accounting literature. The author argue in the introduction part of his paper that there is no comprehensive, or unifying, theory of disclosure, or at least none that he felted confortable to identify. In the disclosure literature, there is no central paradigm, no signale compelling notion that gives rise to all subsequent research, no well-integrated theory, however one interprets that term. In its current composition the disclosure literature could probably best be characterized as an eclectic commingling of highly idiosyncratic and highly stylized, economic-based models, each of which ateempts to examine some small piece of the overall disclosure puzzle. Eclecticism is exacerbated by the fact that disclosure, as a topic, spans three literatures: accounting, finance and economics, and thus inevitably takes on features of those literatures.

In his mentioned work Verrecchia (2001) attempted a taxonomy of the extant accounting literature on disclosure and suggested three broad categories of disclosure research in accounting:

- association-based disclosure;

- discretionary-based disclosure;

- efficiency-based disclosure.

The first category of research, association-based disclosure have as a primary concern how exogeous disclosure is associated with, or related to, the change of disruption in the activities of investors who compete in capital market settings as individual, welfare-maximizing agents. The distinguishing feature of work in this category is that studies the effects of exogenous disclosure on the aggregate or cumulative change in investors' actions, primarily through the behavior of asset equilibrium prices and trading volume.

The second category, discretionary-based disclosure, examined how managers and/or firms exercised discretion with regard to the disclosure of information about which they may have knowledge. The distinguishing feature of work in this category is that treats disclosure as endogenous by considering managers' and/or firms' incetives to disclose information known to them. Typically this is realized in the context of capital market setting in which the market is characterized as a single, representative consumer of diclosed information.

The third category, efficiency-based disclosure, discussed which disclosure arrangements are preferred in the absence of prior knowledge of the information, that is ex ante. The distinguish feature of work in this category is that it examines unconditional disclosure choices; typically this is 
done in the context of a capital market setting in which the actions of individual, welfaremaximizing agents are endogenous.

Accounting research in the utilization of corporate website as a tool to disclose information began to emerge in the end of 1990s. Pioneer articles wrote by Pirchegger and Wagenhoffer (1999), Gowthorpe and Amat (1999) or Hedlin (1999) are descriptive or explorative and inferential reserach on this issue began to emerge in the 2000s. Scholars usually investigate two different internetrelated variables in their articles:

- Internet financial reporting (IFR) - to what extent companies incorporate their financial statements in their corporate website;

- Internet-based disclosure - to what extent companies disclose their information, financial and/or non-financial, in their website.

As Prabowo and Ankoso pointed out in their article (2006) - Factors influencing the extent of Web-based Disclosure: An Empirical Analysis of Indonesian Manufacturing Firms- although these variables are different they are the same at one point: IFR and web-based disclosure are both voluntary disclosure practices. In their opinion, IFR is voluntary not because of the content of information, but because securities market regulator does not stipulate companies to inform their financial statements in their website, even the possession of website is neither stipulated. On the other hand, web-based disclosure is voluntary because of both the content of information and the way information is transferred through Internet. Although, they are both voluntary in nature, webbased disclosure is much broader than IFR.

Debreceny, Gray and Rahman (2002) analysing the determinants of IFR came to a conclusion regarding the empirical studies conducted on voluntary disclosure. These previous studies suggest that managers voluntarily enhance the visibility of their companies' financial profiles to:

(1) reduce agency costs or contracting costs (Chow and Wong-Boren, 1987);

(2) reduce its cost of capital (Botosan, 1997 and Sengupta, 1998);

(3) enhance the value of the firm (King et. Al, 1990; Yeo and Ziebart, 1995 and Frankel et. al, 1999)

These studies have identified certain characteristics of the firm that can increase or reduce certain firm costs. They show that disclosure can individually or simultaneously reduce agency and contracting costs, cost of capital and/or increase firm value. For instance, companies aim to lower their average cost of capital by listing on foreign exchanges. However, foreign listing extends the dispersion of shareholders, which, in turn, increases the information asymetry between managers and shareholders because foreign shareholders do not understand the disclosure rules of the company's home country. Another example is, the time taken to transmit disclosures to foreign investors. Therefore, the reduction of cost of capital through foreign listing might only be achieved if further initiatives are taken to improve the understandability and timeliness of the disclosures.

Also we are in accordance with Debreceny, Gray and Rahman (2002) regarding the issue of financial reporting disclosure environment. As previos researchers pointed out the disclosure environment includes:

- varios dimensions of national culture (Gray, 1988);

- the nature of financing (Ball, 1995; Nobes 1998); and

- regulatory arangements (Ball et. al., 2000).

Gray (1998) explained that differing patterns in the cultural variables between countries has led to differing patterns of accounting and varying levels of corporate disclosure.

\section{Previous researches concercing voluntary disclosure practices on the Internet}

The accounting literature on disclosure frequently cites the agency concept as providing incentives for mandatory and voluntary disclosure of financial information. These incentives are 
viewed in the literature as predominantly driven by the need to reduce information asymmetry between principals and agents. Stakeholders (principals) use accounting information to monitor the performance of management (agents). In turn, these agents use accounting disclosure as an opportunity to signal their performance to their various principals (Watts and Zimmerman 1986; Healy and Palepu 2001). Financial reporting and voluntary disclosure on the Internet has become an increasingly attractive research topic. Prior studies are mainly descriptive or reflective, comparative or explorative. The descriptive studies conducted by Lymer (1997), Deller, Stubenrath \& Weber (1999), Asbaugh, Johnstone \& Warfield (1999) studied survey the current state of financial reporting on the Internet.

Based on such theories as agency theory, signalling theory, or innovation diffusion theory, a number of more recent studies have examined the determinants of Internet based corporate disclosure (Ettredge, Richardson \& Scholz, 2002; Debreceny et. al., 2002; and Xiao et. al., 2004). Many determinats have been tested, usually based on the studies of hardcopy corporate disclosures. These include company size, leverage, industry type, listing status, profitability, auditor type and intangible assets. Ashbaugh et al. (1999), Craven and Marston (1999), and Ettredge et. al (2001) discovered that larger U.S. and U.K. companies are more likely to provide financial information on the Internet. On the other hand studies done by Pirchegger and Wagenhofer (1999) find that whereas company size and profitability affect the corporate disclosure of Austrian companies, they do not affect German companies' disclosure choises. Also studying the determinants of voluntary corporate disclosure in the U.S., Ettredge et. al (2002) realize a distinction between disclosure of items that are mandated by the SEC and those not required by regulation. Up here, we may conclude that the findings indicate that the former are associated with company size and information asymmetry between the company and investors whereas the latter vary with company size, information asymmetry, demand for external capital, and disclosure reputation. However, the study only examines the content aspect of disclosure.

Although several studies examining the determinants of voluntary disclosure of financial and non-financial information through the Internet already exist, this theme has been explored very little in individual nations. In Litan and Wallison's vision (2000) the demand and supply side implications of the Internet for corporate disclosure are profound. If companies can use the Internet to access information almost constantly and instantaneously - and investors and analysts have a thirst for such information - the obvious result will be much more continous reporting of financial and business information. Much, if not all, of this information should be designed to help investors better estimate companies' future profitability and relative riskiness, so that they can more accurately price companies' true market values.

In dealing with the determinants of financial information disclosure on the Web, Marston and Leow studied a sample of companies in the UK and concluded that the size of a firm is positively related to the disclosure of financial information on the corporate website. However, this relationship was not uniform between the varied industrial sectors considered in the study. Leftwich, Watts and Zimmerman's (1981) find a relationship between external capital suppliers and company managers, an example of the agency relationship, where the capital suppliers represent the principal and the company managers represent the agents. Agency theory, which derives its roots from the conflict of interests between stockholders and managers, is discussed by Berle and Means (1932), with a more modern explanation by Jensen and Meckling (1976). This theory suggests that agency costs of borrowed capital depend on the nature of the objectives of the external suppliers of capital. This indicates that the costs would be proportional higher for the companies with greater participation from third-party capital in their capital structure. Additionally, Jensen and Meckling (1976) concluded that voluntary disclosure can reduce agency costs by facilitating the capital suppliers' evaluation of a company's ability to assume debt.

Even though there is a considerable body of research regarding relationships between voluntary disclosure of financial information and financial leverage, a consensus has not been 
reached on the topic. While some studies (Mitchell, Chia and Loh, 1995; Hossain, Berera and Rahman, 1995) reveal a positive relationship between voluntary disclosure and leverage in the capital structure of a company, others do not support these results. For instance, authors like Mckinnon and Dalimunthe (1993), Aitken, Hooper and Pickering (1997), or Brennan and Hourigan (2000) did not find a significant positive relationship between leverage and the level of disclosure of financial information. Some authors (Meek, Roberts and Gray, 1995) suggest there might be a significant negative relationship. The results offered from these studies are inconclusive.

Prabowo and Angkoso (2006) find out in their research about the factors influencing the extent of web-based disclosure, with an empirical study about Indonesian manufacturing companies, that leverage positively affects web disclosure. Using the same Indonesian context, Prabowo and Tambotoh (2005) cannot support the hypothesis that level of leverage influences the extent of IFR. Findings of Prabowo and Angkoso (2006) confirms the theory of agency conflict between shareholders and debtholders. The fact that debt only contribute $20,99 \%$ of total capital makes debtholders more vulnerable from agency problems since they are only minority supplier of capital. Debreceny et al. (2002) find that voluntary adoption of Internet corporate disclosure in 22 countries is associated with company size and listing on an U.S. stock exchange, but not with leverage, risk and Internet penetration in the countries. This study in oposition to Ettredge et. al (2002) distinguishes between presentation format and disclosure content. It finds that the level of technology and disclosure environment are associated with presentation format, but not with content. However, the study does not distinguish the disclosures of mandatory versus nonmandatory items.

Studying Internet corporate disclosure in China, Xiao et. al (2004) find out that there is a significant and a positive relation between mandated and voluntary disclosure. They further show that the presentation format of Internet corporate disclosure is associated with the employment of a Big-5 auditor and whether the company is in the information technology industry, while a negative association exists between profitability and the voluntary disclosures. Voluntary Internet corporate disclosure is positively and significantly associated with the proportion of legal person ownership, but not with ownership by domestic private investors, foreign investors and the state. Moreover, the proportion of independent directors has a positive relation with presentation format, voluntary disclosures and the availability of English web pages.

Research on voluntary disclosure choises or factors influencing the extent of web-based disclosure, using Romanian context is still very rare. To our best knowledge, only a few authors investigated this issue: Tiron Tudor (2006), Tiron Tudor, Cristea S. (2006), Ionascu M., Mihai S., and Ionascu I., (2008), Fekete Sz. (2008), Popa A..(2008). Tiron Tudor A. (2006) focused on disclosure and transparency of Romanian listed companies, searching to find out the practices of these companies regarding the IFR and web-based disclosed financial and non-financial information. On the other hand, Ionascu M., Mihai S., and Ionascu I., (2008), are interested in disclosure quality, disclosure regulations and the cost of capital evaluating the impact of IAS/IFRS regulations on the cost of capital for Romanian companies.

\section{Capital market in Romania}

In 1995, after 50 years of absence, the Bucharest Stock Exchange (BSE) had reopened its trading floor. Low volumes of traded shares, turnover and market capitalization are common for the first five years of operating of the BSE. The main factors are considered: the high interests granted by banks, the continuously depreciation of the Romanian currency, the uncertainty of the Romanian investments' regulation, the neglecting of International Monetary Fund agreements, the Balkan war or the decline of Asian stock exchanges that generated the capital withdrawal from the emergent markets. Starting with 2005 the capital market entered a new stage of development. The reorganization process has started and consisted in the retrogradation of the listed companies with 
low liquidity, the adoption of the specific regulation, the harmonization of the Romanian laws with European Directives. Therefore, the upward trend of Romanian economy determined the inflation reduction, lower return for bank deposits and the increase of the active investors on the stock exchange and turnover, also.

Regarding the regulations on the topic, the new Capital Market Law being in force starting July 2004 was adopted in order to harmonize the Romanian capital market legislation with the EU legislation and to consolidate in one single law all the provisions concerning the autochtonous capital market. This new Capital Market Law introduced the concept of quarterly reports, an improvement related to corporate governance principles and disclosure issues. Although, the new law implements only partially the OECD recommendations regarding best international standards and practices in corporate governance, as enumerated in the White Paper on Corporate Governance in South East Europe. The "Plan for medium term development of the Romanian capital market" issued by the National Securities Commission in 2004 contained medium term objectives about issuer transparency and disclosure (Tiron Tudor, 2006): establishment of listing rules according to the European regulations; establishment of rules regarding periodic audited financial statements; elaboration of conformity rules with the European regulations regarding price sensitive information; improvement of rules regarding public offers.

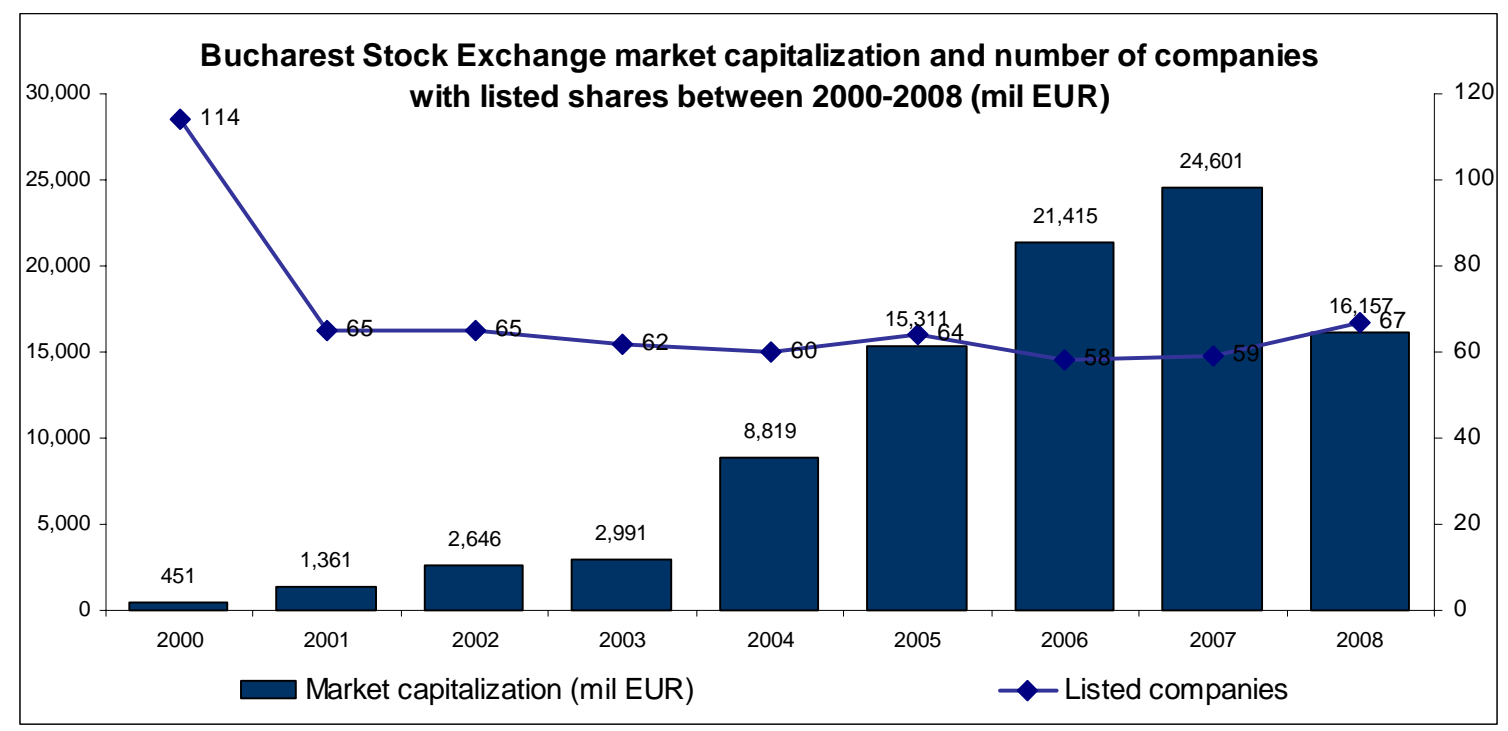

Source: $w w w . b v b . r o$

\section{Figure no.1 - The evolution of Bucharest Stock Exchange market capitalization (in mil Euro) and number of companies with listed shares between 2000 and 2008.}

As it can be seen in the figure 1, the market capitalization has exponentially increased year by year, starting with 2000 even if the number of companies with listed shares has declined. Every year has brought new historical maximum, the market being characterized by higher liquidity and increased market capitalization. 


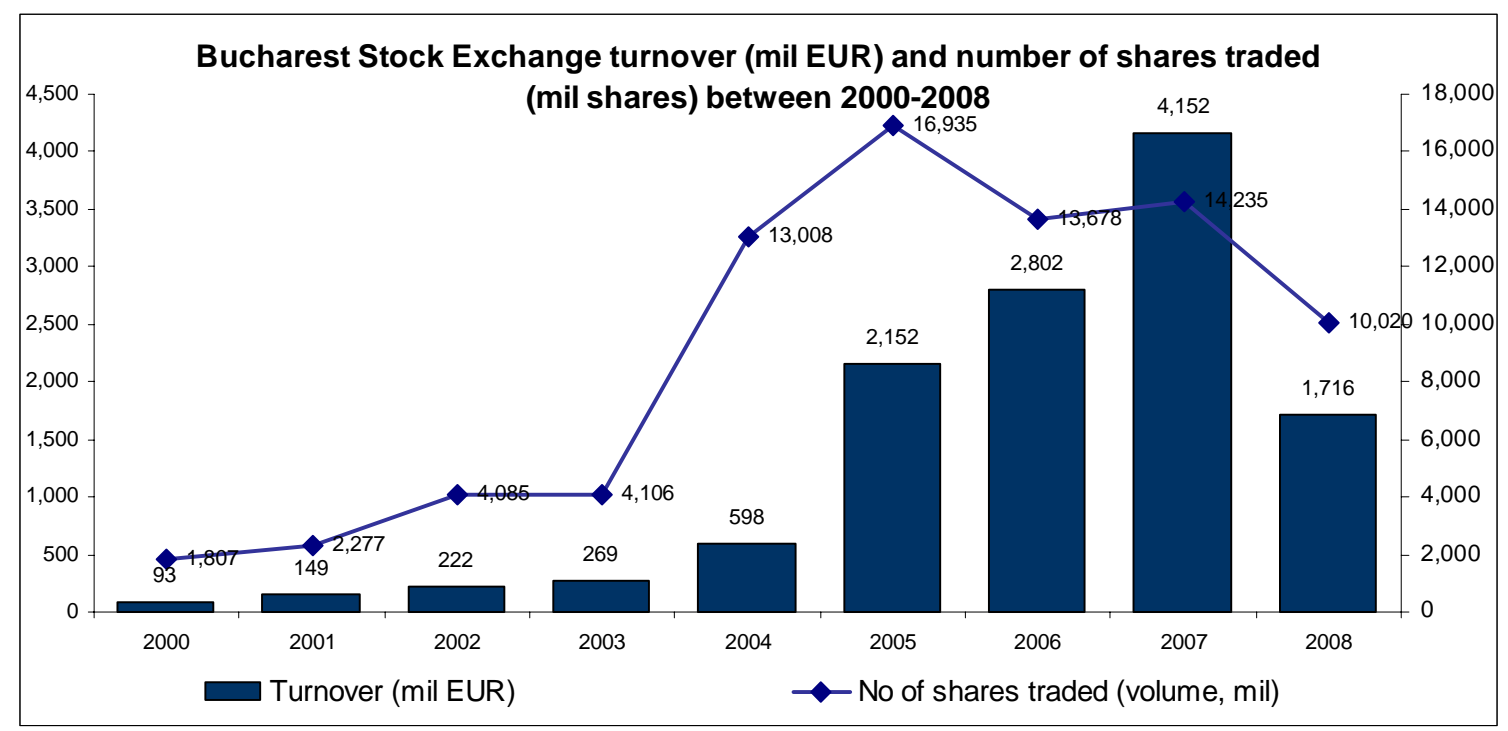

Source: www.bvb.ro

Figure no. 2 - The evolution of Bucharest Stock Exchange turnover (in mil Euro) and number of shares traded (in mil shares) between 2000 and 2008.

The figure no 2 reveal the same ascending trend both of the Romanian stock exchange turnover and number of shares traded. The reasons of the spectacular dynamic are the low initial values of the shares and the tendencies on the capital market, characterized by an increased volatility and a more differentiated evolution of the individual quotations, a fact which created opportunities also for speculation. Even if the BSE has recorded increasing market capitalization year by year, the table no 1 reveal that Romania is the last country in the region by the weight of market capitalization in Gross Domestic Product. It can be observed that significant progresses have been realized during the last four years, but more effort is still necessary.

Table no. 1

The weight of market capitalization in GDP for Central and East European countries between 2003 and 2006 (\%)

\begin{tabular}{lcccc}
\hline \multicolumn{5}{c}{ \% of market capitalization in GDP } \\
\hline \% & $\mathbf{2 0 0 3}$ & $\mathbf{2 0 0 4}$ & $\mathbf{2 0 0 5}$ & $\mathbf{2 0 0 6}$ \\
\hline Bulgaria & 7,80 & 10,60 & 20,10 & 33,24 \\
\hline Czech Republic & 15,40 & 25,10 & 31,60 & 37,95 \\
\hline Hungary & 18,00 & 25,90 & 31,40 & 34,60 \\
\hline Poland & 14,80 & 26,60 & 33,00 & 43,04 \\
\hline Romania & 5,90 & 15,00 & 19,30 & 25,44 \\
\hline Slovakia & 7,60 & 30,59 & 31,54 & 32,48 \\
\hline
\end{tabular}

Source: www.cnvmr.ro.

Presently, the largest first six companies listed on BSE share $44.47 \%$ of total market capitalization, out of which, Petrom SA (symbol SNP), the largest listed company, has $19.59 \%$ of the whole BSE capitalization. Even if almost half of market capitalization is shared between six companies, as the Romanian capital market become mature and the number of listed companies will increase, the companies' market capitalization will be balanced. (i.e. two years ago, in October 2006, Petrom recorded $46 \%$ of whole market capitalization). 


\section{Research design and key findings for BSE listed companies}

In order to develop Romania has to attract foreign investments into the country. To promote confidence and encourage investors Romanian companies should meet stakeholders' demands for greater speed and volume of transparent and timely financial information. Certainly, the Internet can provide better and more effective ways of communicating financial and non-financial information. Therefore, there is a need to analyze the role played by the Internet in disclosure financial and non-financial information in Romania in order to find out how that role may be enhanced.

This study covers the companies listed on Bucharest Stock Exchange at the end of 2007. The authors have taken all the companies of $\mathrm{I}^{\text {st }}$ and $\mathrm{II}^{\text {nd }}$ categories listed on BSE as the population of this study due to the fact that the number of companies is small and it is convenient to collect data related to it. The population consists of 60 companies divided into 10 sectors of activity according to BSE classification; the figure no. 3 shows the structure of BSE market capitalization by sector of activity. Financial Investmetns Companies (S.I.F.) were excluded from the study due to the fact that they are particular Romanian closed-end investment company and their value is formed from other listed companies.

Figure no. 3

The structure of stock market capitalization according to activity sectors.

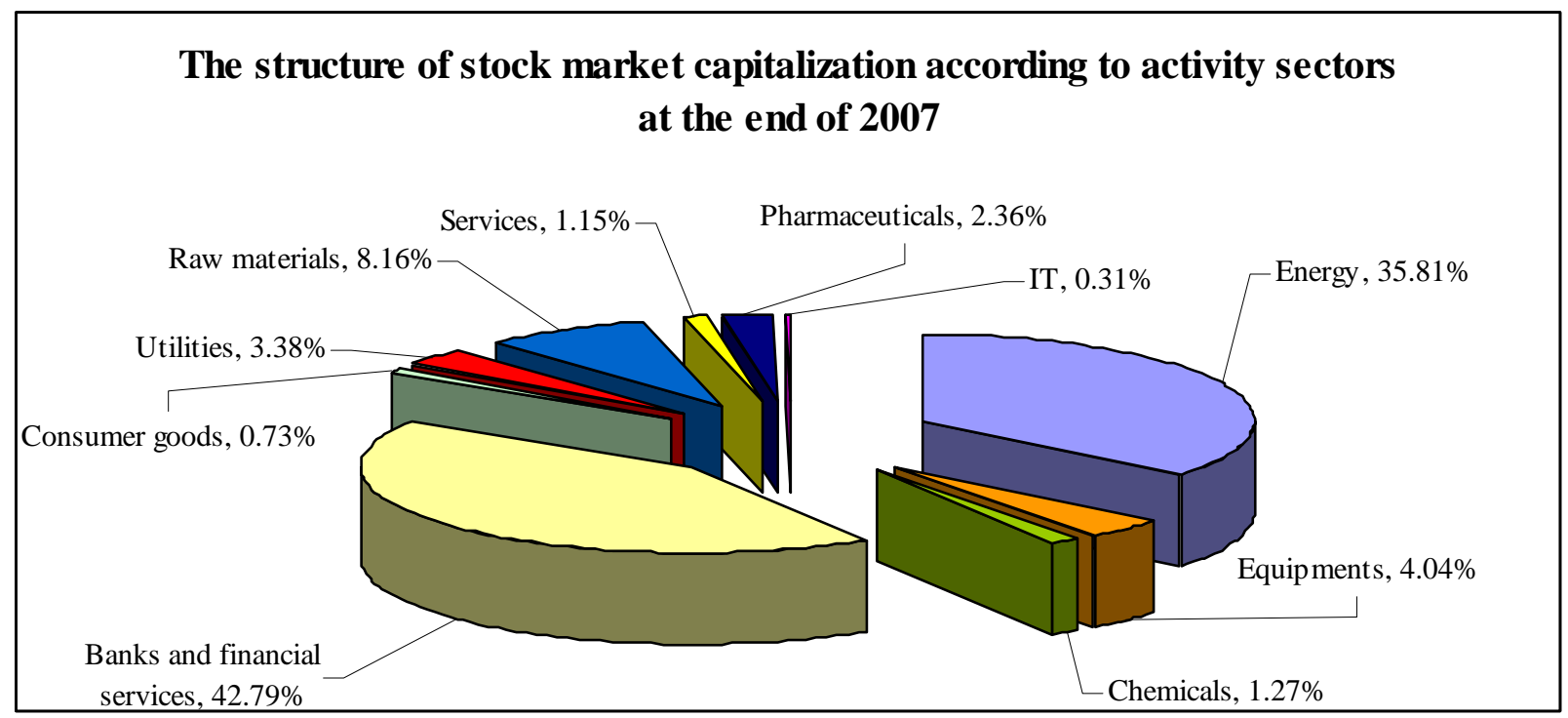

Source: Bucharest Stock Exchange, Monthly Bulletin, December 2007.

Companies were surveyed between May 2007 and May 2008 to find out whether they have websites or not, searching also for data regarding the voluntary disclosure of financial and nonfinancial information. All the data was gathered from the following sources: www.bvb.ro, www.cnvmr.ro, www.ktd.ro and www.kmarket.ro, sites providing stock exchange information and sites of companies listed on Ist and IInd BSE categories; we have collected the data for determining the market capitalization of the companies listed on BSE and also a part of the accounting and financial information regarding the financial statements and annual reports for the years 2006 and 2007; the database provided by the Reuters Press Agency regarding the market prices of the companies from the sample to determine the market capitalizations; the accounting and financial information obtained from the site of the Romanian Ministry of Economy and Finance.

Sample companies are selected purposively. Authors used the following criteria to select the sample companies: 
- own websites;

- positive profitability (EPS and ROA);

- disclosure of financial information (in annual reports, financial statements and financial highlights -ratios);

- audit reports.

The mentioned criteria leave only 23 companies as the research sample. The selection process of the sample can be seen from Table 2 below.

Table no. 2 .

Sample Selection Process

\begin{tabular}{|c|c|}
\hline Explanation & Amount \\
\hline $\begin{array}{c}\text { Population (companies listed on Ist and IInd BSE categories } \\
\text { except Financial Investmetns Companies - S.I.F.) }\end{array}$ & 60 \\
\hline $\begin{array}{c}\text { Less companies with no websites or websites under construction } \\
\text { (or unable to open) }\end{array}$ & $(14)$ \\
\hline Companies left & 46 \\
\hline Less companies with negative EPS and ROA & $(8)$ \\
\hline Companies left & 38 \\
\hline Less companies that do not disclose financial information & $(9)$ \\
\hline Companies left & 29 \\
\hline Less companies that do not have an audit report & $(6)$ \\
\hline Final sample & 23 \\
\hline
\end{tabular}

In the classification of companies, our study is based on the methodology used by Oyelere et al. (2003) and Matherly and Burton (2005). According to Oyelere et al. (2003) companies were classified into three categories concerning the disclosure of financial information:

1. companies that have a website and report financial information

2. companies that have a website and do not report financial information

3. companies without a website.

Analyzing the extent of web-based disclosure, Matherly and Burton (2005) found 34 indicators of web corporate disclosure grouped into five categories:

1. business data

2. forward-looking data

3. company background

4. intangibles

5. convenience

This information is used by them in order to measure the web-based disclosure of US publicly listed manufacturing companies.

As a main aspect concerning mandatory and voluntary disclosure throughout Internet we have to point out that for Romanian listed companies unfortunately there is no legal requirement to post the financial and non-financial information on the Web. Only the BSE Code of Corporate Governance contains a special provision related to publishing financial and non-financial information on the Web.

Tiron Tudor et al. (2004) found that in 2004 the number of listed companies at BSE was 60. The authors have analyzed the access to information - mainly financial information and the results were that 25 companies $(42.37 \%)$ had websites without financial information or links for financial statements and/or annual reports, 20 companies (33.89\%) had web-sites including financial information or links for financial statements and/or annual reports at various levels and 12 companies (20.34\%) had no web-site. Compared with 2005, according to Tiron Tudor (2006) the number of listed companies at BSE was 64. The access to information - mainly financial 
information - through websites was analyzed and the results showed that approximately $80 \%$ of the sample companies have a Web page.

Our study revealed that at the end of 2007 from the population that we have been selected to conduct the research (companies listed on $\mathrm{I}^{\mathrm{st}}$ nad $\mathrm{II}^{\text {nd }}$ BSE categories except Financial Investments Companies - S.I.F.) only 46 companies have an active website that can be accessed in Romanian or both in Romanian and English. Out of theses, we have found that 38 companies recorded positive profitability measured by us through EPS and ROA ratios at the end of 2007 . The sample process leaved further on 29 companies after we have studied the disclosure of financial information. Finally, our study pointed out that only 23 companies listed on $\mathrm{I}^{\text {st }}$ nad II $^{\text {nd }}$ BSE categories, have an audit report posted on their own websites beside other financial information.

As a main result, we have calculated that $76.66 \%$ of the studied companies have a website of their own, out of which only $48.33 \%$ disclose financial data throughout their websites.

Our final sample consisting of 23 companies was analyzed further on, from the following perspectives:

- the extent and quality of the Annual Report;

- shareholder structure (public or private ownership and domestic or foreign ownership).

Regarding the extent and quality of the Annual Reports we have found that only 7 companies from the selected sample disclose various information like: company background, company evolution, marketing strategies, management issues and also much financial information, trends and evolutions of the most relevant ratios. Companies like Antibiotice Iasi, Compa Sibiu, Santierul Naval Orsova or Petrom SA disclose much more data outdistanced from other companies. For instance, Antibiotice SA disclose throughout the own website in English information about company background like: mission and values, history, board chairman's statement, domestic market, international market, management team and board of directors. We have found also data about shareholders, product portfolio, export brochure, quality policy, and drug safety. The company voluntary discloses financial information about stock quotes presenting the evolution of shares during 2000-2008, specificaly: number of issued shares, share quota, market capitalization at the end of the year, dividend per share, PER at the end of the year.

From the selected companies $17.39 \%$ have public ownership as majority; while $34.78 \%$ have foreign shareholders as majority. An interesting topic for our research in the future it will be to test if percentage of private ownership positively affects the extent of web-based disclosure and also if percentage of foreign ownership affects the same way the extent of financial and non-financial information via Internet.

\section{Conclusions, limits and further research}

\section{Concluding remarks}

Our study aims to research the way financial and other non-financial information are communicated throughout the websites by Romanian listed companies and to analyse the criteria in order to select properly the sample companies. A pilot study was conducted searching for the websites of all listed companies registered as category Ist and IInd at BSE. The search revealed that companies which had websites were included among the most actively traded companies. This was expected as only active companies are likely to have websites and disclose financial information on the websites. Therefore it was decided to focus upon the most active companies traded on the Bucharest Stock Exchange. Financial Investments Companies were excluded from the study. Data was collected from companies' websites between May 2007 and May 2008. As websites differed in design and layout, collecting the data was not a routine process. These websites were revisited in June 2008 as a validity check and no changes in the companies' websites were found. In the case of companies whose websites were under construction or unable to access, it was confirmed that they were still unavailable up to the end of June. 
As a major conclusion to our study, it can be reveled that at the end of June 2008, a large number of Romanian listed companies only made mandatory or advisory disclosure available on their own websites. Moreover, these companies still show a preference for traditional means of communication. It can be confirmed that among the companies analysed, there is still an attachment to traditional paper-based ways of communication. This is shown both in contents, form or tools used for communication on websites. The results above mentioned by us speak for themselves. From our point of view these companies seem to consider the web as an "information deposit" rather than a dynamic means of communication. We consider that this situation could be caused by a lack of external stimuli, due to the lack of regulation on website disclosure.

\section{Limitations}

The study and the results of our research have limitations. The main limitation of our study is the fact that we have not taken into account the determinants of the Internet Financial Reporting, so we have not measured the impact of these factors on the extent of web-based disclosure of financial and non financial information. We have analysed only the criteria that could explain the practice of web-based disclosure among Romanian listed companies. If we look upon the main limitations of our results we can conclude that there are four types of limits: time period; sample size; communication vehicle and the methodology used. These limits may affect the generalizability of the findings.

\section{Directions for further research}

A few ideas on the direction for future research is outlined below which is based on the results and experience from writing this study. First of all, this article contributes to our understanding on the role of accounting information on the capital market. However, the realized research uses only secondary sources of information downloadable from the sites that we have mentioned in the previous section above. Mostly, we have studied the annual report, the financial statements and some financial ratios posted on the websites by the sampled companies. Another way forward could be to study more specific cases focusing on one industry to get a more accurate understanding of which factors lay behind the extent of web-based disclosure and using descriptive statistics and regression models to measure the influence of these factors upon the practice of disclosure among listed Romanian companies. Another direction of research it could be an approach that could lead to a better understanding of the role of accounting information for fundamental analysis. And finally, in our opinion it would be worthy to conduct a comparative and qualitative (or quantitative too) study between the CEE countries regarding the extent of web-based disclosure practices and IFR.

\section{References}

1. Akerlof G., „The Market for Lemons”: Quality Uncertainty and the Market Mechanism”, Quarterly Journal of Economics, 1970, p. 629-650.

2. Avallone F., Veneziani M., ,Models of Financial Disclosure on the Internet: A Survey of Italian Companies", Working Paper No.24, presented at the 25th annual European Accounting Association Congress, Copenhagen, April 2002, p. 8-30.

3. Bagnoli M., Watts S.G., „Financial Reporting and Supplemental Voluntary Disclosures”, Working Paper No. 1186, 2006, p. 1-11.

4. Botosan Ch.A., „Disclosure Level and the Cost of Equity Capital”, The Accounting Review, vol.72, 1997, No.3, p. 323-349.

5. Cooke T., „An Assessment of Voluntary Disclosure in the Annual Reports of Japanese Corporations", The International Journal of Accounting 26, 1991, p. 174-189.

6. Debreceny R., Gray G.L., Rahman A., ,, The Determinants of Internet Financial Reporting”, Journal of Accounting and Public Policy 21, 2002, p. 371-394. 
7. Ettredge M., Richardson V.J., Scholz S., „Dissemination of Information for Investors at Corporate Websites", Journal of Accounting and Public Policy 21, 2002, p. 357-369.

8. Gray L., „Financial Reporting on the Internet” - Instant, Economical, Global Communication, 2004, http://www.ifac.org/Library/SpeechArticle.html.

9. Healy P.M., Palepu K.G., „, Information Assymetry, Corporate Disclosure and the Capital Markets: A Review of the Empirical Disclosure Literature”, Journal of Accounting and Economics, 2001, p. 373-381.

10. Ionascu M., Mihai S., Ionascu I., „Disclosure quality, disclosure regulations and the cost of capital", Journal of Accounting and Management Information Systems, No. 24/2008, p. 722.

11. Khan T., „Financial Reporting Disclosure on the Internet: An International Perspective”, Doctor of Philosophy Thesis, Victoria University, Footscray Park, Victoria, Australia, 2006, pp. 39-43.

12. Matherly M., Burton H.A., „An Analysis of Corporate Website Disclosures”, Management Accounting Quarterly 6(2), 2005, p. 26-33.

13. Oyelere P., Laswad F., Fisher R., ,, Determinants of Internet Financial Reporting by New Zealand Companies", Journal of International Financial Management and Accounting 14(1), 2003, p. 26-63.

14. Prabowo R., Angkoso K.S., „Factors Influencing the Extent of Web-Based Disclosure: An Empirical Analysis of Indonesian Manufacturing Firms”, Jurnal Akuntansi Dan Keuangan, vol.8, No.2., November, 2006, p. 92-98.

15. Raffournier B., „, The Determinants of Voluntary Financial Disclosure by Swiss Listed companies", The European Accounting Review, 1995, p. 261-280.

16. Tiron Tudor A., „Disclosure and transparency of Romanian listed companies”, 2006, available online at http://papers.ssrn.com/sol3/papers.cfm?abstract_id=920580/28.07.2008

17. Verrecchia R.E., ,Essays on Disclosure”, Journal of Accounting and Economics, 32, 2001, p. 3-42.

18. Xiao J.Z., Yang H., Chow C.W., „The Determinants and Characteristics of Voluntary Internet-based Disclosures by Listed Chinese Companies, Journal of Accounting and Public Policy 23, 2004, p. 191-225.

19. http://www.pfsprogram.org/capitalmarkets research.php/ 28.02.2008.

20. www.bvb.ro.

21. www.cnvmr.ro.

22. www.ktd.ro.

23. www.kmarket.ro.

24. www.mfinante.ro. 